\title{
Logistics Integrated Planning METHODS OF DisTRIBUTING TOURS IN A COOPERATIVE ASSEMBLY SYSTEM
}

\author{
OLAH, B.; BANYAI, T. \& CSELENYI, J.
}

Abstract: The events that led up to this scientific work that the detailed in the former publications analysis of assignment algorithms of assembly plants to the final product requirements of the end users in a cooperative assembly system we take homogeneous shuttle tours (direct delivery) into account by the determination of the objective function as a simplified cost function. Leaning on the before-described model the work details that the solution of distribution tasks by the help of round tours generates a cost reduction for shuttles. The authors review the description of the algorithms for route planning and the different round tour types such as collecting tour from assembly plants to an end user, distribution tour from an assembly plant to end users, and both models of mixed tour (distributing tour attendant upon collection and combined round tour) in the first chapter. The elaborated heuristic algorithms are demonstrated by a simple example considering different round tour types in the next part of the scientific paper. Finally we discuss in detail the evaluation and comparison of investigational results of methods (shuttle and round tour) adjunct to showed models, and determination of further tasks for optimal operation of the distribution system for instance the modification of the vehicle capacity, and the effects of change of cost elements and data structure.

Key words: Logistics, Assembly plant, End user, Distributing tour, Network, Planning, Final product, Round tour
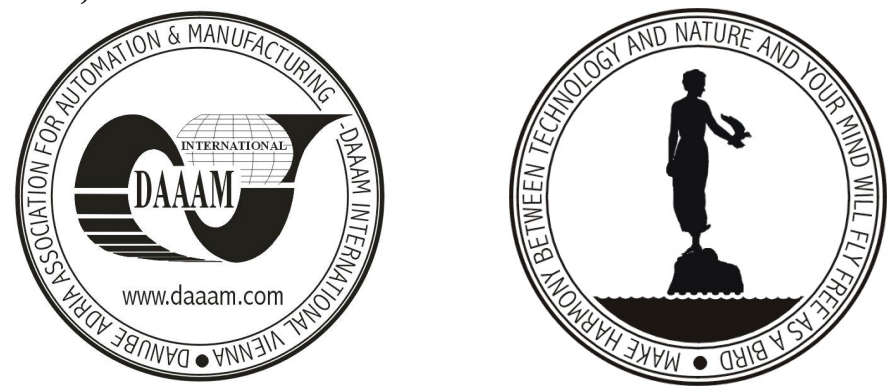

Authors' data: M. Sc. Olah B.[ela]*, Ph.D. Banyai T.[amas]**, Ph.D. Cselenyi J.[ozsef]**, *Szolnok College Technical and Agricultural Faculty Mezotur, **University of Miskolc Department of Materials Handling and Logistics, Hungaria, olahb@mfk.hu, alttamas@uni-miskolc.hu,gkalt@uni-miskolc.hu

This Publication has to be referred as: Olah, B.; Banyai, T. \& Cselenyi, J. (2006). Logistics Integrated Planning Methods of Distributing Tours in a Cooperative Assembly System, Chapter 36 in DAAAM International Scientific Book 2006, B. Katalinic (Ed.), Published by DAAAM International, ISBN 3-901509-47-X, ISSN 1726-9687, Vienna, Austria

DOI: $10.2507 /$ daaam.scibook.2006.36 